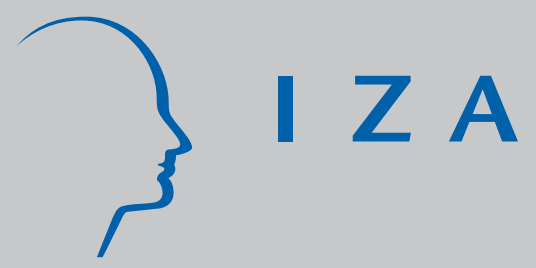

IZA DP No. 12

Determinants of International Migration: Empirical Evidence for Migration from Developing Countries to Germany

Ralph Rotte

Michael Vogler

J une 1998 


\title{
DETERMINANTS OF INTERNATIONAL MIGRATION: EMPIRICAL EVIDENCE FOR MIGRATION FROM DEVELOPING COUNTRIES TO GERMANY
}

\author{
Ralph Rotte \\ Michael Vogler
}

Discussion Paper No. 12
June 1998

IZA

P.O. Box 7240

D-53072 Bonn

Germany

Tel: +49-228-3894-201

Fax: +49-228-3894-210

Email: iza@iza.org

This Discussion Paper is issued within the framework of IZA's research area Internationalization of Labor Markets and European Integration. Any opinions expressed here are those of the author(s) and not those of the institute. Research disseminated by IZA may include views on policy, but the institute itself takes no institutional policy positions.

The Institute for the Study of Labor (IZA) in Bonn is a local and virtual international research center and a place of communication between science, politics and business. IZA is an independent, nonprofit limited liability company (Gesellschaft mit beschränkter Haftung) supported by the Deutsche Post AG. The center is associated with the University of Bonn and offers a stimulating research environment through its research networks, research support, and visitors and doctoral programs. IZA engages in (i) original and internationally competitive research in all fields of labor economics, (ii) development of policy concepts, and (iii) dissemination of research results and concepts to the interested public. The current research program deals with (1) mobility and flexibility of labor markets, (2) internationalization of labor markets and European integration, (3) the welfare state and labor markets, (4) labor markets in transition, (5) the future of work, and (6) general labor economics.

IZA Discussion Papers often represent preliminary work and are circulated to encourage discussion. Citation of such a paper should account for its provisional character. 
IZA Discussion Paper No. 12

June 1998

\begin{abstract}
Determinants of International Migration: Empirical Evidence for Migration from Developing Countries to Germany*
\end{abstract}

By means of a descriptive survey of theoretical literature the paper first works out the potential determinants that may drive international migration from developing to developed countries. Furthermore, we look on the relationship between trade, development and migration. Empirical studies focusing on international migration from LDCs so far are very scarce. The paper utilizes a new dataset that is based on migration from 86 African and Asian countries to Germany. Information is available on overall moves (1981-1995) and asylum migration (1984-1995). The estimation results confirm the importance of the economic differential between countries for migration, the existence of an inverse u-shaped relationship between development and migration, as well as the importance of the political situation in sending countries and of network effects.

JEL Classification: F22, O15, O19

Keywords: migration, international migration, developing countries

Michael Vogler

SELAPO - Universität München

Ludwigstr. $28 \mathrm{RG}$

D - 80359 München

Germany

Tel.: +49-89-2180-2891

Fax: +49-89-336392

email: Michael.Vogler@selapo.vwl.uni-muenchen.de

The authors thank Christoph M. Schmidt, Timothy J. Hatton and the participants of the international workshop "Hunger and Migration: Historical and Current Perspectives" in Heidelberg, October 1997, for helpful comments and suggestions on earlier drafts of this paper. 


\section{Introduction}

Given the general increase of global migratory movements there are more and more persons making their way to the western industrialized countries. Within Europe, Germany is the country which was the destination of the clearly biggest migration inflows in the recent decades. Like in most other European states this has led to further restrictions of immigration. On the other hand in the industrialized countries has been some political insight that only a reduction of the great differences in living standards can lower migration pressure. Trade liberalization has been perceived as the most adequate way to reach this goal, in part within the framework of regional integration. The Mediterranean agreements of the EU and the NAFTA are examples for this approach. This policy, however, is mainly based on theoretical considerations and on empirical knowledge about internal migration or migration between (neighboring) countries with similar levels of development. There is only very limited information about factors driving international migration from the developing countries to the industrialized world. In fact there are some surprising stylized facts: Despite enormous differences to the living standards in the industrialized countries, the major part of economic and political migration takes place among developing countries. Only relatively small numbers of people actually come to the industrialized countries. On the other hand, there is some evidence that rising wealth in LDCs could be accompanied by increased migration, at least in the short- and medium-run. By using a new rich data set, this paper intends to make a contribution to the empirical knowledge about the determinants of international migration.

By means of a descriptive survey of the theoretical literature the paper first works out the determinants that may drive international migration from developing to developed countries. Chapter 2 looks at models that relax the restrictive neoclassical assumptions like homogenous individuals, perfect markets, complete information, as well on the "new economics of labor migration'. Furthermore we discuss some aspects from a macroeconomic view, e.g. selfselection, migration pressure, push and pull and self-propelling migration. Chapter 3 takes account of the relationship of trade, development and migration. Economic history shows some interesting parallels between the present situation of the LDCs and overseas European migration from the mid-19th century. We also have a look at the impact of some instruments which seem useful for the promotion of development: trade, direct investment and development aid.

In the course of this paper we look for new empirical evidence for the theoretical 
considerations given before. The paper utilizes a new dataset that is based on migration from 86 African and Asian countries to Germany. Part 4 gives the description of the dataset. Information is available on overall moves (1981-1995) and asylum migration (1984-1995). Together with the explanatory variables on economic, political and social conditions, we obtain a panel data set which we have analyzed using a random effects model. Chapter 5 presents the estimation results. The parallel analysis of asylum migration and total migration gives some additional interesting insights, as well as the distinction of African and Asian sending countries. The estimation results confirm the importance of the economic differential between countries, the existence of an inverse $\mathrm{u}$-shaped relationship between development and migration, as well as the importance of the political situation in sending countries and of network effects.

\section{A survey of migration theory and some conclusions for international migration from developing countries}

The starting point of most models explaining the migration decision is the neoclassical approach, according to which different economic opportunities, especially wages, are the main reason for migration (Hicks, 1932). In the pure neoclassical framework individuals act rationally, have all accessible information, and a perfect knowledge about the future. There is full employment and migration is not associated with any costs. These restrictive assumptions have been eased step by step in order to explain some important empirical results. The common ground of all those models, however, remains the perspective of migration as an income maximizing individual's decision. Contrary to this view, the 'new economics of migration' looks at the household as core decision maker. In this approach, migration is a strategy of risk diversification for the households. Moreover, the importance of the relative income situation for the migration decision is emphasized. There is a whole range of publications giving detailed overviews of the formal implementation of those approaches. See for example Straubhaar (1988); e.g. Bhattacharya (1993) and Ghatak, Levine und Price (1996) for a special assessment of the neoclassical approach; e.g. Stark (1991) for the 'new economics of migration'. There periodically also were surveys of recent empirical evidence, see e.g. Krugman and Bhagwati (1976), Greenwood (1985) and Bauer and Zimmermann (1995). In the following part, we look at the central elements of the theoretical considerations in relation to international migration from the LDCs to industrialized countries, as well as some special aspects from a macroeconomic perspective. Empirical evidence for this type of 
migration is very scarce.

\section{Microeconomic Approaches}

The human capital approach to migration was in its fundamental elements presented by Sjaastad (1962), giving up the assumption of homogeneous labor. Individual labor market characteristics and the different payment of these characteristics in different regions result in migration being worthwhile for some individuals in a country and not for others. This plays an important role in the analysis of emigrants' self-selection which we will deal with below. Moreover, the human capital approach loosens the assumption of perfect markets since the importance of migration costs is stressed. These costs do not only consist of pure transport costs but also of income losses during migration and of e.g. psychological costs from the loss of one's familiar environment. Migration is interpreted as an investment since the present costs have to pay off in the future. High costs, possibly corresponding with a high rate of time preference, in the human capital theory provide one explanation of the relatively low immigration from the LDCs into the industrialized countries. The human capital approach also gives a theoretical argument for the observation of most empirical studies that found decreasing migration incentives with aging (see Bauer and Zimmermann (1995) for an overview). This can be explained by the fewer number of time periods during which the migration investment may pay off. Todaro (1969) and Harris and Todaro (1970) gave up the neoclassical assumption of full employment and looked at the migration from rural areas to the cities in the LDCs, which took place despite high unemployment in urban areas. Then, for the migration decision, the expected income is relevant which is the wage times the probability of getting a job. The importance of job probabilities and urban unemployment rates were proved true by many empirical studies, see Todaro (1980) for a survey of ruralurban migration in developing countries. However, the basic theoretical considerations can be transferred to international migration as well. This means that even in case of a little probability of getting a job in an industrialized country, it may be worthwhile even for an individual employed in a LDC to move, if the wage differential is sufficiently high. In an extension of this approach one could additionally take account of the existence of social security systems which means that unemployment does not necessarily mean to be without any income. Since these systems are typically better established in the industrialized countries, there may be an higher incentive to migrate, even if one does not expect to find a 
job from the start.

The Harris-Todaro model was a first step to account for uncertainty associated with migration. In this model, however, one assumes that the probability of getting a job is known. Therefore, in a further step the costs of gaining information was incorporated. No potential migrant will spend unlimited resources in order to get information about various target countries. There are models which try to formulate explicitly the search behavior (e.g. Maier, 1985, Berninghaus and Seifert-Vogt, 1991). The fundamental result is that the search pays off only as long as its expenditures are smaller than the expected gain from further search. In different approaches more or less individual knowledge about his principal wage opportunities is assumed. Given the prerequisites described, the potential migrant may decide for the 'second best' solution. In case of migration from a totally different world region the search costs will be extremely high and thus provide an explanation why so many people in developing countries prefer non-migration to the North. Uncertainty and false expectations about a target country are also connected to the aspect of temporary migration, return migration or transit, although these cases are also possible without uncertainty and may be planned in advance based on some foreseeable development of wages and sufficiently low migration costs. Dustmann (1994) hints at the role of potentially lower living costs in the country of origin for the decision to return home, which may be also planned before initial emigration. McCall and McCall (1987) argue that certain information is available only in the country of destination and realizing unfavorable circumstances in this way may result in return migration. Other models assume that there is some option value of provisional nonmigration or waiting (Burda, 1995), since the investment in migration is generally irreversible or at least only at very high costs. It could be disadvantageous to migrate now if the development in the home country is unexpectedly positive or unexpectedly negative in the target country. If this is not the case one may still migrate in the next period when one has acquired more information on the further development. Concerning international migration from the LDCs, these models with uncertainty possibly provide some very important factors in actual migration from developing countries. While some basic information about the countries of destination like approximate income level and unemployment should be relatively easy to find, this is certainly not the case for e.g. individual employment opportunities. This uncertainty is even more important if one assumes that the majority of individuals is risk-averse or hope for an unexpectedly better development in the home 
country. On the other hand, there is decreasing uncertainty caused by modern communication technologies like satellite TV, which might be an explanation for persistently rising migration in the recent decades. Another point for rising migration might be network effects which we will turn to below.

The so-called 'new economics of migration' takes a different view of the microeconomic determinants of migration. Their motivation were some observations in the LDCs which could not be explained by the extended neoclassical approach. Therefore, according to the 'new economics of migration', it is not the individual who is decision-maker but the household or the family respectively. Although it is also possible to analyze migration as a family decision within the neoclassical framework (Mincer, 1978), the perspective of the New Economics is a fundamentally different one. Individual family members migrate because the dependence on the situation in single labor markets is reduced. Similar to a portfolio decision of an investor there is risk reduction by diversification. Closely related to this aspect are remittances from the emigrants, which can be seen as the outcome of an implicit contract with their families stayed behind (Stark, 1991). This form of risk diversification is a particularly important aspect in LDCs where public social security is inadequate, and working private capital markets are rare. Remittances are often the biggest part of household budgets and are also highly important for many LDCs on the macroeconomic level. Another contribution of the 'new economics of migration' is the concept of 'relative deprivation'. Here, it is not one's absolute income which is decisive for migration issues but the individual's relative income position within a society. This provides a theoretical foundation for the empirical observation that migration rates in the poorest regions are not necessarily the highest, and that migration rates often are the higher the higher income inequality is. In brief, there is a higher incentive to migrate if one is poor among rich than if one is poor among poor. See Stark (1991) for an extensive coverage of this aspect, empirical evidence for Mexican internal and international migration, and for the 'new economics of migration' in general.

\section{Analyzing aggregated flows}

From simple consideration using the neoclassical approach follows that, on the macro level, migration is a consequence of wage differentials between regions or countries. Migration is the optimal allocation of the factor labor into regions of highest productivity, leading to a 
equalization of wages if there are no costs of migration. Nearly all empirical studies using aggregated data found wages to have an significant influence on migration, as well as the unemployment rates and so confirmed the Harris-Todaro approach (Bauer and Zimmermann, 1995). One question, however, is how fast adaptation takes place. Equilibrium advocates assume that wages differentials in principle adjust fast, and that persistent differences are based on existing costs and different local amenities. Hunt (1993) explains this approach extensively and shows that it is not empirically sound. In fact, apart from the relatively high costs of migration, it would be quite heroic to interpret the high wage differentials between developing and industrialized countries as consequences of local advantages in the LDCs. Therefore it seems more reasonable to assume a persistent disequilibrium.

Emigrants are not a random sample of a country's population. This aspect has already played an important role in the 'brain drain' debate, concerning emigration of the highly qualified (see e.g. Bhagwati, 1976) and its negative consequences for sending country's economy. The question of self-selection of migrants found renewed attention with analyses of the performance of migrants in the host labor market (see Borjas, 1994, for an overview). A popular model in the migration literature to analyze the self-selection of migrants is the RoyModel. This model was first used by Robinson and Tomes (1982) to analyze internal migration in Canada. A formal representation of this model for the explanation of international migration flows can be found in Borjas (1987). Thus, the relative wage on observable and unobservable abilities in home and host country determines the kind of selection, while the level of income affects the amount of migration. If the income distribution is very inegalitarian the less qualified will migrate, and so there is 'negative selection'. As for instance the numbers of the World Bank (1997) demonstrate, the income distribution in the majority of LDCs is more unequal than in industrialized countries. This would suggest, that most South-North migrants should be negatively selected. Nevertheless, since the level of wages in developing countries is often extremely low, migration according to the Roy model may be attractive for higher qualified persons, too, and actually prevent selection.

In public discussion about present or future international migration from developing or transformation countries, the term 'migration pressure' is often used. Surprisingly, there is no coherent definition even in the scientific literature. Straubhaar (1993) defines migration pressure as the difference of the numbers of those persons willing to migrate under current 
circumstances and those whom the country of destination is prepared to accept. A fundamentally different definition is used by Bruni and Venturini (1995) who argue from the perspective of the sending country. They define migration pressure as excess supply of labor vis-à-vis the demand of labor. Of course there remains the problem that excess labor supply not necessarily results in emigration. Schaeffer (1993) therefore defines migration pressure in terms of effective demand. Among Schaeffer's various definitions for emigration and immigration pressure there is also one for 'excess immigration pressure' in which he takes account of the host country's demand for immigration like Straubhaar (1993).

There is a general consensus that there are factors in the sending and the destination countries which determine whether an existing 'migration potential' results in actual migration. For factors concerning the home country one speaks of so-called 'push' factors, for those concerning the host country one uses the term 'pull' factors. The most important push factors for developing countries are population growth and the corresponding unemployment and poverty, political instability, wars and ecocide. Pull factors are mainly high wages in the industrialized countries, their social security systems and political stability - given the preparedness to accept the migrants. While this frequently used definition of push and pull factors is oriented on whether they occur in the sending or destination country, Zimmermann (1995) defines push and pull within a macro-economic price-output-framework for the host country. According to him, pull factors are all influences which stimulate overall demand. In the standard case of a rising supply and a falling demand curve this leads to increasing prices, output and wages. Rising wages and the changing wage differential provide an incentive for immigration. The resulting increase in labor supply results in a further extension of overall supply and a dampening of inflation. Push migration is defined as an exogenous increase of labor supply due to immigration. This leads to an increase of the national product and a decrease in the price level.

Another question deals with self-propelling migration. From the view point of the receiving countries this aspect is extremely important since it means that allowing current migration will result in ongoing future migration independently from other push or pull factors. A first theoretical explanation for this phenomenon can be found in the concept of 'relative deprivation' mentioned above, when looking on the effects of migration on the distribution of income. When individuals or households leave a region in which they feel relatively deprived, another group now find itself at the end of the income scale and eventually now has an incentive to migrate, too. On the other hand, if not 
whole households migrate but only dispatched individuals, remittances may lead to a significant shift in the income distribution. This may cause other households also to let members migrate. See Stark (1991) for an extensive overview. Another cause of persistent migration is the use of financial transfers of previous migrants. For an overview of the literature see Massey (1988). By money transfers some household will be fast able to acquire land so that in the end property will be concentrated in the hands of relatively few households. Due to the income transfers from abroad they need not use the land as intensively as before, which decreases crop production and labor demand, and increases prices and migration incentives (Massey, 1988). Most attention in persistent migration, however, is put on so-called network effects. Existing connections between individuals in a host country and friends and relatives left at home increase the likelihood of the latter following to the country of destination. For, first, the costs of information acquisition are lower. Second, the psychological costs of separation also decrease for the follow-up migrants, since they already have contacts in the country of destination which also may help them in finding a job. The uncertainty and the risk of migration are reduced. Independent of the factors causing the original migratory movement, e.g. poverty, war, or simple spirit of adventure, there may develop some self-propelling process. It may be limited to certain regions or population groups of the home country at first, but is likely to expand to all groups in time (Massey, 1988). As Bauer and Zimmermann (1995) show in a survey of empirical studies on internal and international migration, included network variables in general were always found to be significant.

\section{Development and migration - is there an u-shaped relationship?}

The (according to their view) too high immigration and the fear of a further growing influx has led to a new political focus on immigration in the EU countries. Difficult labor market situations and restrained social security budgets have been a supposedly adequate argument against immigration. Natives' fears associated with immigration have been fostered by rightwing extremist parties and have finally resulted in significantly tougher immigration laws (see e.g. Heckmann and Bosswick, 1995). At the same time, there has been growing awareness of the need to take up the conditions in the sending countries in order to reduce emigration incentives and to prevent people from illegal immigration in view of cut legal ways. Three economic instruments are in the center of discussion: trade liberalization, direct investment, and development aid. Most hopes are pinned on intensified trade 
which is to be fostered for instance by regional economic integration (e.g. Russell and Teitelbaum, 1991). The reduction of current and especially of future migration pressure was a major motivation for the Mediterranean Cooperation of the EU or creation of NAFTA. This policy, however, is mainly based on theoretical considerations and on empirical knowledge about internal migration or migration between (neighboring) countries with similar levels of development. There is only very limited information about factors driving international migration from developing countries to the industrialized world. Nevertheless, there are empirical observations hinting only at an long-run success of this strategy at best. Paradoxically, rising wealth seems to be connected to increased migration in the short and medium run. We turn to this problem in this section.

\section{Lessons from History}

The present situation of many LDCs and the obviously increasing emigration pressure has some interesting parallels in the past, especially in the European migration to the New World in the second half of the 19th century. There are several studies which have analyzed the relationship of economic development in Europe and emigration. See Massey (1988) and Hatton and Williamson (1994) for an overview. One basic result is that economic development was necessarily associated with migration. Technical progress increased agricultural productivity and released workers. The number of small farmers decreased as well as the bonds to the countryside. On the other hand mechanization and progressing division of labor increased labor demand and wages in the cities. No European country achieved industrial transformation without urbanization which was mainly driven by migration from the countryside into the cities. Since the urban centers could not absorb all of the migrants, many went overseas. In the countries of the New World there was excess demand for labor and a relatively high living standard. Thus, internal and international migration were consequences of the same process. Massey (1988) has shown that the beginning of industrialization was also the starting point of significant emigration in every European country. Two points are most interesting since they are in contrast to theoretical considerations: Most migration actually did not originate in the poorest European countries, and in the first decades rising economic wealth led to an increase of migration. Great Britain which experienced the earliest and the strongest economic development, had also the highest emigration rate. 
As a consequence of industrial transformation there was also the beginning of the phase of demographic transition in 19th century Europe, with rising fertility and falling mortality. Like currently in many developing countries, there was an enormous population growth. Easterlin (1961) and others therefore have asked whether emigration was also an outlet for this demographic development. If it was, migration should be high for countries with high natural population growth. Easterlin (1961) interpreted population growth as a proxy for the growth of the labor force and the corresponding ability of the labor market to absorb it. Hatton and Williamson (1994) have emphasized that even with constant absorption ability, a higher emigration rate can result from a higher number of individuals reaching an age in which they are prepared to migrate. As mentioned, according to the human capital approach, migration is most likely at the beginning of the working life. Thus the question is, to what degree population growth had a direct impact on migration, or if it was the situation on the labor market which was decisive in the end. Easterlin (1961) concentrated his analysis on two main aspects, the natural population growth and the per-capita income. By controlling for the other factor in each case, he found a positive relationship between emigration and population growth and a negative one between emigration and per-capita income. However, the percapita income could be only interpreted as a very crude indicator for the situation on the labor market and thus for economic opportunities of workers. A further interesting result was, that the higher the population growth the more sensitive the emigration seemed to be to changes of it. Conversely the sensitiveness to changes of the per-capita income seemed to be higher at lower levels of wealth.

One basic problem of early studies on European emigration, like for current studies of migration from the LDCs has been the available data on wages. Usually, only rough estimates of per capita income could be used. Hatton and Williamson (1994) had a much more relevant measure of income for the migration decision available: internationally comparable real wages of unqualified, urban male workers. This was the group of persons with the highest tendency to migrate. Hatton and Williamson (1994) also found a positive impact of lagged population growth on migration, which gave a hint at the direct effect of demographic development on migration since they controlled for the relative labor market situation. This was done by inclusion of the wage differentials, which had a positive effect on emigration. Apart from the consequences for wages there was only a weak impact of industrialization, i.e. of the societal change mentioned above. Network effects, however, played an important role. The additional inclusion of home country wages and its quadratic led to the right 
signs, but were not statistically significant. Thus there could not found any effects of possibly vanishing financial restrictions with development.

All together the studies on European migration found a relationship between development and migration, that is still interesting for the current and future immigration from the developing countries. At the beginning of industrialization one could observe low wages and low migration rates. With rising development there was an acceleration of emigration and only in the long run a reduction of wage differentials led to lower migration rates. Thus there were an inverse u-shape relationship between economic development and migration. The increasing number of emigrants in early periods of industrialization could be mainly explained by direct and indirect effects of demographic transition and expanding networks. Industrialization itself or societal change respectively, as well as vanishing financial restrictions seem to had only minor importance. The experience of European emigration, that development resulted in an persistent and self-accelerating process in the short- and medium-run, is a interesting lesson with regard to actual and future migration from developing countries to developed countries. It contradicts the hope of many policy-makers in industrialized countries to lower the migration pressure in near future by fostering growth in developing countries. Nevertheless, it is significant differences in the labor market situations and generally in living standards which are the root causes of economic migration in the end. Only the equalization of living conditions led to decreased migratory movements from European countries to the New World.

An interesting result also comes from the experience of intra-European migration. Today, only few people migrate between the countries of the European Union, despite the principle of free movement of labor and persisting high differences in living standards. The situation was fundamentally different in the 1950s and 1960s when many guestworkers from the south European states went to northern Europe. See Straubhaar (1988) for a detailed analysis of push and pull factors driving this migration. Faini and Venturini (1993) have found an inverse u-shaped relationship between development and migration for south European countries. They give an interesting explanation for the observation that the likelihood of migration decreases in advanced stages of development, even if one controls for wage differentials. If there is a preference for staying in the home country, rising living standards result in a positive income effect concerning staying at home, although the differential to potential destination countries remains the same or might even increase. For the current migration from the LDCs this would mean that accelerated growth may 
lead to a reduction of migration incentives in the long run, even if there is no significant closure of the income gap to the industrialized countries.

\section{Fostering development in the South}

What are the instruments for accelerating economic advance in the LDCs? Trade liberalization is considered to be most promising. The consequences of liberalization can be analyzed in the framework of a Heckscher-Ohlin model (see e.g. Ethier, 1986). In this case, a removal of restrictions leads to the countries' specialization in production of the goods for which they have relatively abundant supply of input factors and thus have a comparative cost advantage. For developing countries, this would certainly be labor, in the industrialized countries capital. Assuming a not totally divergent factor supply, trade will result in equalization of factor prices and a reduction of migration incentives. If factor supplies are too different, there is at least some convergence of factor prices. In any case there is a substitutional relationship between trade and migration in this model. Starting from the basic learning that free trade is beneficial for both sides, granting trade preferences plays an important role in German and EU development policy. On the other hand there is still strong protectionism especially for labor intensive goods, in which the LDCs have an absolute and a relative cost advantage. At the same time, most developing countries have given up their policy of import substitution in the recent decades, and have moved to a more outwardoriented trade policy (see Krueger (1997) for an overview).

The straightforward result of the Heckscher-Ohlin model concerning the relationship of trade and migration has been frequently questioned. Markusen (1983) has shown that trade and migration can be complements if trade has causes other than different factor supplies, e.g. different technologies or scale effects in production. There is a multitude of other aspects which could justify complementarity of trade and migration, see e.g. Schiff (1996) and Martin and Taylor (1996). Richards (1994) analyzes the experience of some developing countries in liberalizing trade. Her descriptive analyses suggest that if there is a link between trade and migration it is a complementary one. However, concerning South-North migration one cannot deny an important role of actual differences in factor supplies and thus eventually some basic substitutionality of trade and migration. Nevertheless, factors possibly leading to short and medium term complementarity are again dissolution of financial restrictions with rising income and sinking migration costs through emerging networks. Moreover, there is the 
question about the impact of absolute cost advantages of the industrialized countries, which may exist in most areas. These may be enrooted e.g. in a far better infrastructure and make even production of labor intensive goods worthwhile at best by employing immigrant labor. This effect is empirically supported by the observation that in industrialized countries, the foreigner share is highest in sectors with strong import competition (see e.g. Zimmermann, 1992). Thus, an improvement in the supply of some basic complementary inputs in the LDCs would be necessary to realize the fundamentally existing comparative advantage (Martin and Taylor, 1996).

Based on the Heckscher-Ohlin model an equalization of factor prices can also result from movement of the other factor, capital. Using the slogan 'Jobs to the people, instead of people to the jobs', direct investment of the industrialized countries in the LDCs is seen as an adequate instrument to promote southern development by growth and creation of jobs, and thus to decrease emigration incentives. Bhagwati and Srinivasan (1983) have shown that, from the sending countries' welfare perspective, such capital transfers are preferable to emigration. When analyzing the importance of FDI one has only to hint at the success of the east Asian 'tigers' whose rise mainly depended on foreign, especially on Japanese investment. See e.g. Ito (1994) for an analysis of Japanese investment in the ASEAN countries and their impact on migration. Although there are still significant migratory movements from these countries, they have changed to net immigration countries. Nevertheless, investment is more dependent on the conditions of the sending country than trade. LDCs can only count on foreign investment if there is political stability and the economic prerequisites are favorable. On the other hand, the industrialized countries' influence on direct investment is limited since, first of all, it is decisions on the firm level. In the view of the industrialized countries, direct investment abroad may also mean a shift of jobs to low wage countries. Since LDCs have often only rudimentary social security systems and many countries try to secure cost advantages by use of child labor, direct investment is not unconditionally supported by the industrialized countries.

If there is factor price convergence, direct investment, like trade, should result in a decrease of migration incentives, given that improved living standards do not lead to higher migration because of loosened budget restrictions or lower migration costs. The same applies to development aid as another instrument to promote better living standards. The political advantage of development aid is mainly the more direct control by the industrialized countries, compared to trade and direct investment. As e.g. Rotte (1996) 
emphasizes, development aid during the Cold War was a primary instrument to keep developing nations aligned with the capitalist West or the communist East. More often than not, the financial means supported mainly the ruling dictators and clans. The demise of the socialist systems provided an opportunity for reorientation. First, it is at least an official intention to connect development aid to the acceptance of human rights and democracy, in order to put pressure on authoritarian regimes and to reduce the political incentives for migration. Second, the assistance can be used more thoroughly for a decrease of economic migration incentives, by promotion of growth, rising income and job creation. There are various possibilities, like grants, credits, technical assistance by transfer of personnel and technology (see e.g. Breier, 1994). Böhning and Schloeter-Parades (1994) present several studies on the impact of development aid on migration.

In brief, what one can say about the relationship of development and migration is that there are many hints according to which economic advance in the LDCs, by trade liberalization, direct investment or development aid, could result in increased migration in the short and medium run. Only in the long run migration incentives can be expected to be reduced. It remains an empirical problem whether there is really a significant 'migration hump' and when a change in the trend of migration can be expected. Faini and Venturini (1994), though for migration from South-North migration within Europe, estimated the turning point in the income-migration link at around US\$ 4,000 in 1985 prices. Due to a lack of data, knowledge on the determinants of migration from LDCs is scarce. In an analysis of immigration from 17 developing countries, Rotte et al. (1997) could only find an increase in migration with economic development, but no u-shaped pattern.

\section{Dataset and specification}

The data availability for the analysis of international migration is very unsatisfying and so empirical evidence on the determinants of international migration is scarce. This is especially the case for migration from developing countries. Not only is information missing frequently but also existing data often is not comparable. ILO (1997) gives an extensive survey of the problems. Nevertheless, we have collected a dataset for a special part of the migration issue: international migration from 86 African and Asian countries into Germany. This dataset is first based on the numbers of asylum seekers (1984-1995), as published by the Federal Ministry of the Interior. Second, we have information about total inflows (1981-1995), provided by the Federal Statistical Office relying on information from the local registration 
offices. In Germany registration with the relevant local community is mandatory for every change of place of living. Inflows also cover asylum seekers. In principle, leaving a local community must also be reported, and this information is also available. In practice, however, notices of departure are often omitted by persons leaving Germany, so that available numbers are not very reliable.

Due to the German legal situation, in the period we look at, there were basically only two ways of being granted permanent residence for citizens of the most LDCs: application for asylum or family unification. Additionally, there were special, time-restricted rules for certain groups, e.g. boat people from Vietnam. They, however, were quantitatively negligible. Before the change of the Basic Law in 1993 the application for asylum secured at least temporary residence which could take several years. If the application was refused after this time, many refugees could not be repatriated due to humanitarian reasons. In principle, there was no incentive for the great majority of potential migrants to come to Germany illegally until the change of the constitution. This seems especially reasonable for people from developing countries, whose migration costs are relatively high, and to a lesser degree for citizens of the neighboring east European transformation countries. Germany is the European country which was affected most by the persistently increasing numbers of immigrants from all over the world. In the period covered by our data, more than 50 percent of all asylum seekers in Europe came to Germany, clearly in front of France with 10 percent. As mentioned, the numbers on overall moves in principle include asylum seekers, the balance mainly be immigration of family members.

Our dataset covers most of the African and Asian LDCs. We look at countries from which Germany received immigrants, as well as those without any person coming. Unfortunately, the basic statistics available were not always perfectly broken down. Countries sending only few immigrants were combined as a residue. For 1984, for example, numbers on asylum seekers were broken down only for 19 of 86 countries, which nevertheless covered 98.1 percent. For 1995 it was for 77 out of 86 countries (100 percent). In the case of the total flow data the relation was not that positive: In 1981, numbers were broken down for only 54 countries, covering 96.2 percent of immigrants. For 1995 there was detailed information about 75 countries (99.6 percent). With these numbers, we considered it justifiable to set the number of immigrants from the countries that were not broken down to zero. Figure 1 shows the development of immigration from the countries covered, for asylum 
seekers as well as for the total inflow. One can see e.g. that immigration from Asia was generally clearly higher than from Africa.

The structure of the dataset hints at a regression analysis using a panel model, in either a fixed effects or a random effects estimation (see e.g. Greene, 1993, for a detailed explanation). We used the Hausman test (Hausman, 1978) for the choice between these two alternatives. The test statistics, which are given at the bottom of tables 2 and 3 clearly confirm the appropriateness of the random effects estimator. Furthermore, we tested the random effects model against a pooled OLS model by using a Lagrange multiplier test introduced by Breusch and Pagan (1980) and modified by Baltagi and Li (1990) for unbalanced panel data. It has the null hypothesis that the random effects have a variance of zero in which case random effects provide no better model than OLS. Our test statistics (see also tables 2 and 3) led to a clear rejection of the null hypothesis, indicating that in each case the random effects panel model is preferable to the simple OLS framework.

The first set of explanatory variables cover the influence of economic circumstances. As explained above, in principle these include wages, the unemployment rate as a measure of the occupation opportunity, but also information about the tax and social security systems. It is hardly possible to obtain comparable data on different countries, and for the LDCs these numbers are not available at all in most cases. Like most empirical studies we therefore use GNP per capita as a crude proxy for different living standards. It would be desirable to adjust these numbers to different costs of living in the countries, but unfortunately there is also a lack of information here so that this correction is not possible for a dataset with many different countries. Nevertheless, as the SOEC (1985) has shown for a range of African countries, adjustment for purchasing power parities differently increases income of the LDCs, but the relative position of the countries remains basically unchanged. Thus as an explanatory variable we use an uncorrected GNP per capita ratio of the relevant sending country and Germany. It is to cover the supposed effect of decreasing migration incentives with converging living standards. In order to account for a possible dissolution of financial restrictions and the corresponding inverse u-shaped relationship between development and migration, we also included GNP per capita of the sending country and its square.

Political factors potentially fostering emigration are captured here by the Freedom House Index for political rights and civil liberties, and the Political Terror Scale created by Purdue University, USA. Political rights in the context of the Freedom House Index enable people to participate in the political process, e.g., by free election of 
parliaments actually controlling governments in charge of public affairs, while civil liberties cover the freedom to express views, and to develop institutions and personal autonomy apart from the state, e.g., by freedom of speech, assembly or religion. For each of the two categories there is an index ranging from 1 (totally free) to 7 (not free at all) according to a checklist based on published source materials, reports from human rights organizations and governments, and newspapers. (For details see Freedom House 1991, pp. 1-54.) The overall Freedom House Index on human rights is the sum of the two single indicators. Although indices like this have been vastly criticized in the literature (e.g. Barsh, 1993), to us they seem an appropriate way to obtain at least some quantitative measure of freedom and the human rights situation in the sending countries. In order to capture the degree of actual political violence in a country rather than its general level of liberty, we also use the Political Terror Scale which ranks countries in five categories according to annual country reports of Amnesty International. Group 1 comprises countries with a secure rule of law, while group 5 contains countries where there is state violence against the whole population without limits on the means. For details see Gibney et al. (1996).

As described above, a major role in migration is ascribed to the existence of links between sending and host country. Networks facilitate information acquisition of potential migrants, as well as their adaptation to the new environment of the strange country of destination. In order to measure this effect, we include the number of persons of the same nationality residing in Germany at the beginning of the year as an explanatory variable. Another variable is the volume of trade between the sending country and Germany, i.e. the sum of exports and imports. We want to test the hypothesis that intensified economic contacts lead to an improved information flow and thus to lower migration and search costs. One has to mention here that this variable certainly does not allow an assessment of substitutionality of complementarity of trade and migration. In order to obtain relevant results on this question it would be necessary to find a specification containing the overall volume of trade of the LDC and at best total emigration as well.

Another set of variables is to cover certain characteristics of the sending country. First, it is reasonable to control for the population. The higher the population the higher is the potential stock of migrants, ceteris paribus. Second, as shown, one may expect that with advancing industrialization and the corresponding migration from the countryside into the cities, international migration will also rise. To account for this effect we include the share of urban population in total population.

Third, another frequently supposed 
determinant of migration is population growth. As mentioned above, there is some evidence that there is a lagged effect of population growth by about twenty years, due to individuals reaching the age of migration or being confronted with a dense labor market. To cover this effect we include the growth of labor force as an explanatory variable. Fourth, we use distance to the host country as a proxy for direct migration costs. We suppose, however, that the explanatory power of this variable will not be very high since in our data set migratory movements take place over one thousand of kilometers in the minimum case. Direct costs like flight tickets should not vary as much for higher distances.

Among further control variables there were dummies for restrictive legal measures taken in Germany in 1987 and 1993. From a formal point of view, the tougher reforms took place in 1993, with the change of the Basic Law. Additionally, we include a time trend. Given that the other exogenous variables account for a multitude of time-dependent effects (e.g. by networks), it is to cover improved communication and transportation links due to technical progress. Table 1 gives a list of variables, their definition and descriptive statistics.

\section{Estimation results}

Specification. Table 2 presents various estimations for the total dataset, i.e. for African and Asian countries combined. Columns (1) and (4) show our preferred complete specification. The other columns give some alternatives in order to test the stability of our results. In specification (2) and (5) we left out the stock of migrants from the sending country in Germany. Immigration numbers have increased strongly only since the early 1980s and the immigrants who arrived in the last period can be considered as having a huge share of the migrant stock. Therefore one could suppose that the migrant stock could be highly correlated with the other exogenous variables, because these variables possibly not have changed very much in one period and thus have influenced the migration flow in the period before. As one can see from the table, however, there are little changes in the overall picture provided by the estimations if the migrant stock is left out. Population in the home country becomes positive and significant, but correlation between these variables is not surprising. It is more unexpected that the population stock is not significant in the complete specification - we will come back to this issue below. We do not have a good explanation for the growth of the labor force becoming significantly positive in case of asylum migration, and significantly negative for total inflows. In another alternative

(columns (3) and (6)) we left out the 
trend variable. We also supposed that there was high correlation with other variables, especially with the time dummies for the changes in law. Exclusion of the trend, however, had no effect on the significance of the variables and only a minor one on the coefficients' magnitude. Following the literature, we also experimented with estimations using a lagged endogenous variable. As a consequence, the economic and political variables had hardly any impact any more. This is not surprising because one would expect a high correlation between endogenous and lagged endogenous variable when using yearly data and relatively weakly varying exogenous variables. For technical reasons it seems therefore justified not to account for this variable. In a further step we estimated separate models for Africa and Asia, where we used the complete specification (Table 3).

Economic opportunities. As expected from the standard models on migration we found a negative impact of the wage differential on immigration. For the Asian countries, however, it was not significant at a 10\%-level. Concerning the development of GNP per capita in the sending countries there was also a somewhat mixed result. As explained, this variable was meant to cover the potential effect of loosening financial restrictions. For the asylum migration there was no significant inverse u-shape pattern which we had expected. For the total sample and for Africa migration increases with rising GNP per capita, while there is no significant effect for Asia. Nevertheless, for the inflows we found the inverse ushape in almost every estimation. Overall, it is not surprising that asylum migration is obviously less influenced by economic aspects, although there are many economic migrants who try to get access to Germany via the asylum procedure.

Political situation. A very interesting finding results from the distinction of personal freedoms and government repression. In all estimations we see that political rights and civil liberties have no impact on asylum migration, but political terror against the population of the sending country clearly has. On the other hand improved political rights lead to higher overall moves inflows while political terror is irrelevant. The latter result is very surprising because inflows incorporate asylum seekers. Our suspicion that the two political variables could be collinear, and that a negative effect of political rights might cancel out an existing effect of terror was not confirmed. Alternative estimations leaving out one political variable did not change sign and significance of the other. Thus we conclude that asylum migration is significantly influenced by political terror in the home country, while political rights and liberties have no impact. Inflows which to a large degree depend on family reunification 
increase with political rights and freedom. This seems sensible since, after all, the bureaucratic hurdles are easier to take in a more liberal state.

Links to Germany. As one can see from the tables, there was the expected positive effect of the migrant stock in Germany in most estimations. This confirms the importance of network effects for the information flow to the sending countries and the support of follow-up migrants. No consistent picture was found for the trade variable. While in the case of asylum migration in total and for Africa there is a negative effect, it is significantly positive for the inflows in the total sample and for Asia. Basically, we expected a positive effect because of the connection of trade and information flows, and multinational firms possibly acquire employees directly in the country of origin. A possible explanation for this effect being negative could be that there is less trade with a country ruled by a terror regime, e.g. due to political restraint from the industrialized countries like Germany - at least this is often claimed. In this case, there would be high correlation between the political variables and trade. Estimations we did with trade as the endogenous variable showed in fact that political liberties have a slightly significant (on the 10 percent level), and political terror a strongly significant negative influence when controlling for other exogenous factors like distance and population.

Home country characteristics. One of the most surprising results of our estimations was that the population stock of the sending countries has hardly any impact of migration. In principle a highly populated country should have a higher migration potential, ceteris paribus. As Table 2 shows, there is some correlation with the stock of migrants in Germany. When the latter variable was left out of the estimations, the population stock became highly significant both for asylum migration and total inflows. For the share of urbanized population as well as for the growth of labor force there were few significance and partly contradicting results. We expected that a rising share of urbanized population should be corresponding with increased international migration. Moreover, higher growth of the labor force should be associated with a decreasing ability of local labor markets to absorb new workers who would then emigrate. Distance to Germany as a measure for migration costs had the expected negative effect only in the Asian case. We also tried regional dummies but they only seemed to cover distance in an other way. Therefore we retained only the distance variable.

Further controls. Among the other covariates used there were dummies for the changes in law which all had the expected negative coefficient but were not statistically significant in each case. So there is obviously no effect of better 
transportation and information infrastructure, after controlling for a multitude of other influences. After taking account of the numerous other explanatory variables a slightly significant trend was only observable for inflows. In further estimations we also tried various additional exogenous variables, e.g. the number of refugees of a sending country staying in its neighboring countries. This variable, however, was highly correlated with the Political Terror Scale. Since we have only refugee data available for Africa, we decided to use the terror scale. Further, we included the total foreign trade volume of the sending countries in order to measure the degree of their integration into the world economy and to assess substitutionality or complementarity of trade and migration. This variable, however, was highly collinear with GNP per capita. So this problem could be soluble if there were other income data or actual wage information available.

\section{Conclusions}

Empirical evidence on the determinants of migration from the LDCs to the industrialized countries is scarce. There are some interesting stylized facts, like e.g. the small number of actual migrating persons despite huge wage differentials. As shown in this paper the theoretical literature gives some interesting explanations which have been hardly tested by now, due to the bad data situation on south-north-migration. Using a rich new dataset on immigration from 86 countries to Germany this paper has provided some new empirical insights in the determinants of international migration.

The importance of different living standards for migration incentives could be confirmed. Moreover, there was an inverse u-shaped relationship of development and migration from which we conclude that the industrialized countries have to expect higher immigration pressure in the short and medium run if the economic situation of the LDCs improves. The political situation had also a significant impact on migratory movements. Interestingly, asylum migration was, ceteris paribus, a reaction to political terror and not to the degree of political rights and civil liberties. In contrast, total inflows only reacted to political freedom. Network effects have proved to be highly significant. A negative effect of trade relations on asylum migration was surprising. One possible explanation for this finding may be limited economic contacts with repressive regimes. For the inflows trade showed the expected 
positive coefficient. We also controlled for a range of other factors which described the situation in the sending country in more detail. We could not find an effect of industrial change and the corresponding migration from the countryside to the cities. Similarly, increases in the labor force had no significant impact on international migration. Here, theoretical considerations had suggested that stronger growth would overburden local labor markets and make more people migrate. Among the other explanatory variables distance was significant only for Asia. The stricter laws in Germany had the expected effect on immigration. A growing trend to migration which should cover improved infrastructure and communication technology, could not be found. 


\section{References}

Baltagi BH, Li Q (1990) A Lagrange multiplier test for the error components model with incomplete panels. Econometric Reviews 9: 103-107

Barsh, RL (1993) Measuring Human Rights: problems of methodology and purpose. Human Rights Quarterly 15:87-121

Bauer T, Zimmermann KF (1995) Modeling international migration: economic and econometric issues. In: van der Erf R, Heering L (eds) Causes of International Migration. Proceedings of a Workshop, Luxembourg, 14.-16.December 1994. Eurostat, Luxembourg, 95-115

Berninghaus S, Seifert-Vogt HG (1991) International Migration under Incomplete Information. Springer-Verlag, Berlin

Bhagwati JN (1976) The Brain Drain and Taxation, I, II. North-Holland, Amsterdam.

Bhagwati JN, Srinivasan TN (1983) On the choice between capital and labor mobility. Journal of International Economics 14:209-221

Bhattacharya PC (1993) Rural-urban migration in economic development. Journal of Economic Surveys 7:243-281

Böhning WR, Schloeter-Paredes M-L (eds.) (1994) Aid in Place of Migration? International Labor Office, Geneva

Borjas GJ (1987) Self-selection and the earnings of immigrants. American Economic Review 77:531-553.

Borjas GJ (1994) The economics of immigration. Journal of Economic Literature 32:16671717

Breier H (1994) Development and migration: the role of aid and co-operation. In: OECD (ed) Migration and Development: New Partnerships for Co-operation.OECD, Paris, 173186

Breusch TS, Pagan AR (1980) The Lagrange multiplier test and its application to model specification in econometrics. Review of Economic Studies 47:239-253

Bruni M, Venturini A (1995) Pressure to migrate and propensity to emigrate: The case of the Mediterranean Basin. International Labour Review 134: 377-400

Burda MC (1995) Migration and the option value of waiting. CEPR Discussion Paper No. 1229

Dustmann C (1994) Return intentions of migrants: theory and evidence. CEPR Discussion Paper No. 906

Ethier WJ (1986) International trade theory and international migration. In: Oded Stark (ed) Migration, Human Capital and Development, Jai Press, 27-74.

Faini R, Venturini A (1993) Trade, aid and migrations. European Economic Review 37:435442

Faini R, Venturini A (1994) Migration and growth: the experience of Southern Europe. CEPR Discussion Paper No. 964

Freedom House (1991) Freedom in the World: Political Rights and Civil Liberties 19901991. Freedom House, New York.

Ghatak S, Levine P, Price SW (1996) Migration theories and evidence: An assessment. Journal of Economic Surveys 10:159-198

Gibney M, Apodaca C, McCann J (1996) Refugee Flows, the Internally Displaced and Political Violence (1980-1993): An Exploratory Analysis. In: Schmid AP (ed) Whither Refugee? Human Rights Violations and Refugees: Causes and Consequences. LISWO, Leiden.

Greene WH (1993) Econometric Analysis. Macmillan, New York 
Greenwood MJ (1985) Human migration: theory, models, and empirical studies. Journal of Regional Science 25:521-544

Harris JR, Todaro MP (1970) Migration, unemployment and development: a two-sector analysis. American Economic Review 60:126-142

Hatton TJ, Williamson JG (1994) What drove the mass migrations from Europe?. Population and Development Review 20:533-559

Hausman JA (1978) Specification tests in econometrics. Econometrica 46:1251-1271

Heckmann F, Bosswick W (eds) (1995) Migration Policies: A Comparative Perspective. Enke, Stuttgart

Hicks J (1932) The Theory of Wages, MacMillan, London

Hunt GL (1993) Equilibrium and disequilibrium in migration modelling. Regional Science 27:341-149

ILO (1997) International Migration Statistics. International Labour Office, Geneva

Ito S (1994) Japanese direct investment in selected Asian countries and its impact on migration. In: OECD (ed) Migration and Development: New Partnerships for Cooperation. OECD, Paris, 162-172

Krueger AO (1997) Trade policy and economic development. American Economic Review 87:1-22.

Krugman P, Bhagwati JN (1975) The decision to migrate: a survey. In: Bhagwati JN (ed) The Brain Drain and Taxation II: Theory and Empirical Evidence. North-Holland, Amsterdam, 31-51

Maier G (1985) Cumulative causation and selectivity in labor market oriented migration caused by imperfect information. Regional Studies 19:231-241

Markusen J (1983) Factor movements and commodity trade as complements. Journal of International Economics 14:341-356

Martin PL (1994) Reducing emigration pressure: what role can foreign aid play? In: Böhning WR, Schloeter-Paredes M-L (eds) Aid in Place of Migration? International Labor Office, Geneva

Martin PL, Taylor JE (1996) The anatomy of a migration hump. In: OECD (ed) Development Strategy, Employment and Migration. OECD, Paris

Massey DS (1988) Economic development and international migration in comparative perspective. Population and Development Review 14:383-413

McCall BP, McCall JJ (1987) A sequential study of migration and job search. Journal of Labor Economics 5:452-476

Mincer J (1978) Family migration decisions. Journal of Political Economy 86:749-773

Richards A (1994) Trade liberalisation and migration flows: some evidence from developing countries. In: OECD (ed) Migration and Development: New Partnerships for Cooperation. OECD, Paris, 153-161

Robinson C, Tomes N (1982) Self-selection and interprovincial migration in Canada. Canadian Journal of Economics 15:474-502

Rotte R (1996) Das internationale System zwischen Regionalisierun und Globalisierung. Nomos, Baden-Baden.

Rotte R, Vogler M, Zimmermann KF (1997) South-North refugee migration: lessons for development cooperation. Review of Development Economics 1:99-115

Russell SS, Teitelbaum MS (1991) International Migration and International Trade. Mimeo, The World Bank, Washington

Schaeffer PV (1993) A definition of migration pressure based on demand theory. International Migration 31: 43-72

Schiff M (1996) Trade policy and international migration: substitutes or complements? In: 
OECD (ed) Development Strategy, Employment and Migration. OECD, Paris, ???

Sjaastad LA (1962) The costs and returns of human migration. Journal of Political Economy 70:80-93

SOEC (1985) A comparision of purchasing power parities and real economic aggregates in fifteen African countries. Statistical Journal of the United Nations Economic Commission for Europe 3:17-32

Stark O (1991) The Migration of Labor. Basil Blackwell, Cambridge.

Straubhaar T (1988) On the Economics of International Labor Migration. Verlag Paul Haupt, Bern

Straubhaar T (1993) Migration pressure. International Migration 31:5-41

Todaro MP (1969) A model of labour migration and urban employment in less developed countries. American Economic Review 59:138-148

Todaro MP (1980) Internal migration in developing countries: a survey. In: Easterlin RA (ed) Population and Economic Change in Developing Countries. NBER, Chicago.

World Bank (1997) World Development Report 1997. The World Bank, Washington.

Zimmermann KF (1993) Industrial restructuring, unemployment and migration. In: Bekemans L, Tsoukalis L (eds) Europe and Global Economic Interdependence. European Interuniversity Press.

Zimmermann KF (1994) European migration: push and pull. Proceedings of the World Bank Annual Conference on Development Economics, Supplement to the World Bank Economics Review and The World Bank Research Observer, 313-342. 
Table 1: Variable definitions and descriptive statistics

\begin{tabular}{|c|c|c|c|}
\hline Variable & Definitions & Obs. & $\begin{array}{c}\text { Mean } \\
(\text { Std. Dev.) }\end{array}$ \\
\hline Asylum migration & Number of asylum applications. & 983 & $\begin{array}{c}983.98 \\
(2843.5)\end{array}$ \\
\hline Inflow & $\begin{array}{l}\text { Number of registrations at local authorities } \\
\text { (registration is obligatory). }\end{array}$ & 1273 & $\begin{array}{l}1846.36 \\
(7632.2)\end{array}$ \\
\hline Home country GNP p.c. & In US\$ $(1987=100)$. & 1048 & $\begin{array}{l}2138.06 \\
(4116.7)\end{array}$ \\
\hline GNP p.c. ratio & (Home country/Germany). & 1048 & $\begin{array}{c}0.129 \\
(0.261)\end{array}$ \\
\hline Political rights, civil liberties & $\begin{array}{l}\text { Combined Freedom House Index: } 2 \text { (free) - } 14 \text { (not } \\
\text { free). }\end{array}$ & 1248 & $\begin{array}{l}10.528 \\
(2.867)\end{array}$ \\
\hline Political terror scale & $\begin{array}{l}\text { According to Amnesty International: } 1 \text { (no terror) - } 5 \\
\text { (terror without limits). }\end{array}$ & 1169 & $\begin{array}{c}2.948 \\
(1.021)\end{array}$ \\
\hline Migrant stock in Germany & $\begin{array}{l}\text { Stock of nationals of the sending country in Germany } \\
\text { at the beginning of the period. }\end{array}$ & 975 & $\begin{array}{c}32991.4 \\
(199518.2)\end{array}$ \\
\hline Trade with Germany & $\begin{array}{l}\text { Sum of exports to and imports from Germany (in } \\
\text { thousand DM). }\end{array}$ & 1263 & $\begin{array}{c}1625.2 \\
(3026.7)\end{array}$ \\
\hline Share of urban population & Home country, $\%$ of total population. & 1232 & $\begin{array}{c}37.648 \\
(23.110)\end{array}$ \\
\hline Growth of labor force & Home country. & 1245 & $\begin{array}{c}0.028 \\
(0.010)\end{array}$ \\
\hline Population & Home country. & 1216 & $\begin{array}{l}3.52 * 10^{7} \\
\left(1.52 * 10^{8}\right)\end{array}$ \\
\hline Distance to Germany & $\begin{array}{l}\text { Shortest distance between borders of home country } \\
\text { and Germany (in } \mathrm{km} \text { ). }\end{array}$ & 1285 & $\begin{array}{l}5482.1 \\
(2594.5)\end{array}$ \\
\hline Law 87 & $\begin{array}{l}\text { 1=Immigration restrictions in Germany since 1987, } 0 \\
\text { before. }\end{array}$ & 1285 & $\begin{array}{c}0.598 \\
(0.490)\end{array}$ \\
\hline Law 93 & $\begin{array}{l}\text { 1=Immigration restrictions in Germany since 1993, } 0 \\
\text { before. }\end{array}$ & 1285 & $\begin{array}{c}0.198 \\
(0.399)\end{array}$ \\
\hline
\end{tabular}

Notes: 49 African and 37 Asian countries. Period 1981-1995 (asylum migration 1984-1995). 
Table 2: Different specifications

\begin{tabular}{|c|c|c|c|c|c|c|}
\hline \multirow[b]{3}{*}{ Observations } & \multicolumn{3}{|c|}{ Asylum migration } & \multicolumn{3}{|c|}{ Inflow } \\
\hline & (1) & $(2)$ & (3) & (4) & $(5)$ & (6) \\
\hline & 609 & 752 & 609 & 749 & 920 & 749 \\
\hline \multicolumn{7}{|l|}{ Economic opportunities } \\
\hline log GNP p.c. ratio (home/Germany) & $\begin{array}{c}-2.167 * * \\
(-3.7)\end{array}$ & $\begin{array}{c}-1.953 * * \\
(-3.5)\end{array}$ & $\begin{array}{c}-2.587 * * \\
(-6.9)\end{array}$ & $\begin{array}{c}-1.300 * * \\
(-4.2)\end{array}$ & $\begin{array}{c}-1.829 * * \\
(-5.4)\end{array}$ & $\begin{array}{c}-1.708 * * \\
(-6.3)\end{array}$ \\
\hline log home GNP p.c. & $\begin{array}{c}2.775 * * \\
(2.4)\end{array}$ & $\begin{array}{c}2.474 * * \\
(2.2)\end{array}$ & $\begin{array}{c}3.156^{* * *} \\
(2.9)\end{array}$ & $\begin{array}{c}3.090 * * \\
(4.5)\end{array}$ & $\begin{array}{c}3.360 * * \\
(4.5)\end{array}$ & $\begin{array}{c}3.297 * * \\
(4.8)\end{array}$ \\
\hline log home GNP p.c. squared & $\begin{array}{c}-0.081 \\
(-1.1)\end{array}$ & $\begin{array}{c}-0.101 \\
(-1.4)\end{array}$ & $\begin{array}{c}-0.079 \\
(-1.1)\end{array}$ & $\begin{array}{c}-0.148^{* *} \\
(-3.2)\end{array}$ & $\begin{array}{c}-0.177 * * \\
(-3.6)\end{array}$ & $\begin{array}{c}-0.139 * * \\
(-3.0)\end{array}$ \\
\hline \multicolumn{7}{|l|}{ Political situation } \\
\hline political rights, civil liberties & $\begin{array}{c}-0.002 \\
(-0.1)\end{array}$ & $\begin{array}{c}-0.049 \\
(-1.6)\end{array}$ & $\begin{array}{c}0.003 \\
(0.1)\end{array}$ & $\begin{array}{c}-0.090 * * \\
(-4.5)\end{array}$ & $\begin{array}{c}-0.137 * * \\
(-5.9)\end{array}$ & $\begin{array}{c}-0.090 * * \\
(-4.4)\end{array}$ \\
\hline political terror scale & $\begin{array}{c}0.239 * * \\
\quad(3.3)\end{array}$ & $\begin{array}{c}0.299 * * \\
(4.4)\end{array}$ & $\begin{array}{c}0.241^{* *} \\
(3.3)\end{array}$ & $\begin{array}{c}0.026 \\
(0.5)\end{array}$ & $\begin{array}{c}0.005 \\
(0.1)\end{array}$ & $\begin{array}{c}0.030 \\
(0.6)\end{array}$ \\
\hline \multicolumn{7}{|l|}{ Links to Germany } \\
\hline log migrant stock in Germany & $\begin{array}{c}1.319 * * \\
(11.0)\end{array}$ & & $\begin{array}{c}1.337 * * \\
(11.3)\end{array}$ & $\begin{array}{c}0.743 * * \\
(9.5)\end{array}$ & & $\begin{array}{c}0.776^{* *} \\
(10.0)\end{array}$ \\
\hline log trade with Germany & $\begin{array}{c}-0.434 * * \\
(-3.8)\end{array}$ & $\begin{array}{c}-0.278 * * \\
(-2.5)\end{array}$ & $\begin{array}{c}-0.416^{* * *} \\
(-3.7)\end{array}$ & $\begin{array}{c}0.174 * * \\
(2.4)\end{array}$ & $\begin{array}{c}0.257 * * \\
(3.3)\end{array}$ & $\begin{array}{c}0.204^{* *} \\
(2.9)\end{array}$ \\
\hline \multicolumn{7}{|l|}{ Home country characteristics } \\
\hline share of urban population & $\begin{array}{c}0.009 \\
(0.7)\end{array}$ & $\begin{array}{c}0.013 \\
(1.0)\end{array}$ & $\begin{array}{l}0.011 \\
(0.77)\end{array}$ & $\begin{array}{c}-0.014 \\
(-1.6)\end{array}$ & $\begin{array}{c}0.009 \\
(1.0)\end{array}$ & $\begin{array}{c}-0.008 \\
(-0.9)\end{array}$ \\
\hline growth of labor force & $\begin{array}{c}9.010 \\
(0.7)\end{array}$ & $\begin{array}{c}17.240^{* *} \\
(2.5)\end{array}$ & $\begin{array}{l}-8.192 \\
(-0.6)\end{array}$ & $\begin{array}{l}-4.646 \\
(-0.5)\end{array}$ & $\begin{array}{c}-25.843^{* *} \\
(-4.6)\end{array}$ & $\begin{array}{c}-6.080 \\
(-0.7)\end{array}$ \\
\hline log population & $\begin{array}{c}-0.054 \\
(-0.6)\end{array}$ & $\begin{array}{c}0.420 * * \\
(5.5)\end{array}$ & $\begin{array}{c}-0.067 \\
(-0.8)\end{array}$ & $\begin{array}{c}0.090^{*} \\
(1.7)\end{array}$ & $\begin{array}{c}0.397 * * \\
(7.2)\end{array}$ & $\begin{array}{c}0.071 \\
(1.3)\end{array}$ \\
\hline log distance to Germany & $\begin{array}{l}-0.700 \\
(-1.2)\end{array}$ & $\begin{array}{c}-2.970^{* *} \\
(-5.4)\end{array}$ & $\begin{array}{l}-0.638 \\
(-1.2)\end{array}$ & $\begin{array}{c}-1.215^{* *} \\
(-3.4)\end{array}$ & $\begin{array}{c}-2.920^{* *} \\
(-7.3)\end{array}$ & $\begin{array}{c}-1.104 * * \\
(-3.1)\end{array}$ \\
\hline Restrictions of German Law & & & & & & \\
\hline law 87 & $\begin{array}{l}-0.327 \\
(-1.4)\end{array}$ & $\begin{array}{c}-0.437 * * \\
(-2.0)\end{array}$ & $\begin{array}{c}-0.322 \\
(-1.4)\end{array}$ & $\begin{array}{c}-0.603^{* *} \\
(-3.6)\end{array}$ & $\begin{array}{c}-0.901 * * \\
(-4.9)\end{array}$ & $\begin{array}{c}-0.432 * * \\
(-2.7)\end{array}$ \\
\hline law 93 & $\begin{array}{c}-1.276^{* *} * \\
(-6.4)\end{array}$ & $\begin{array}{c}-0.852 * * \\
(-4.5)\end{array}$ & $\begin{array}{c}1.158 * * \\
(-7.4)\end{array}$ & $\begin{array}{c}-0.471 * * \\
(-3.6)\end{array}$ & $\begin{array}{c}-0.133 \\
(-1.0)\end{array}$ & $\begin{array}{c}-0.290 * * \\
(-2.6)\end{array}$ \\
\hline $\begin{array}{l}\text { Trend and constant } \\
\text { trend }\end{array}$ & $\begin{array}{c}0.050 \\
(0.9)\end{array}$ & $\begin{array}{l}0.142 * * \\
(2.8)\end{array}$ & & $\begin{array}{c}0.070 * * \\
(2.8)\end{array}$ & $\begin{array}{l}0.106^{* * *} \\
(3.9)\end{array}$ & \\
\hline constant & $\begin{array}{c}-120.3 \\
(-1.2) \\
\end{array}$ & $\begin{array}{c}-276.7 * * \\
(-2.8)\end{array}$ & $\begin{array}{c}-24.5 * * \\
(-3.61) \\
\end{array}$ & $\begin{array}{c}-147.4 * * \\
(-3.0) \\
\end{array}$ & $\begin{array}{c}-205.7 * * \\
(-3.9)\end{array}$ & $\begin{array}{c}-12.5 * * \\
(-2.8) \\
\end{array}$ \\
\hline Tests & & & & & & \\
\hline $\mathrm{R}^{2}$ & 0.49 & 0.36 & 0.49 & 0.39 & 0.36 & 0.38 \\
\hline Hausmann & 22.1 & 188.8 & 28.4 & 30.9 & 48.7 & 57.5 \\
\hline Breusch-Pagan & 1358.3 & 1896.9 & 1386.5 & 1719.4 & 2377.1 & 1710.2 \\
\hline
\end{tabular}

Note: $* *$ significant on the $5 \%$-level, * significant on the $10 \%$-level (two-side test) 
Table 3: Estimation results

\begin{tabular}{|c|c|c|c|c|c|c|}
\hline \multirow[b]{2}{*}{ Observations } & \multicolumn{3}{|c|}{ Asylum migration } & \multicolumn{3}{|c|}{ Inflow } \\
\hline & $\begin{array}{l}\text { All } \\
609 \\
\end{array}$ & $\begin{array}{c}\text { Africa } \\
367 \\
\end{array}$ & $\begin{array}{c}\text { Asia } \\
242 \\
\end{array}$ & $\begin{array}{l}\text { All } \\
749 \\
\end{array}$ & $\begin{array}{c}\text { Africa } \\
465\end{array}$ & $\begin{array}{c}\text { Asia } \\
284 \\
\end{array}$ \\
\hline Economic opportunities & & & & & & \\
\hline log GNP p.c. ratio (home/Germany) & $\begin{array}{c}-2.167 * * \\
(-3.7)\end{array}$ & $\begin{array}{c}-2.210 * * \\
(-2.6)\end{array}$ & $\begin{array}{c}-1.090 \\
(-1.5)\end{array}$ & $\begin{array}{c}-1.300 * * \\
(-4.2)\end{array}$ & $\begin{array}{c}-1.513 * * \\
(-4.3)\end{array}$ & $\begin{array}{c}-0.597 \\
(-1.2)\end{array}$ \\
\hline log home GNP p.c. & $\begin{array}{c}2.775 * * \\
(2.4)\end{array}$ & $\begin{array}{c}3.775^{*} \\
(1.7)\end{array}$ & $\begin{array}{l}-0.427 \\
(-0.75)\end{array}$ & $\begin{array}{c}3.090 * * \\
(4.5)\end{array}$ & $\begin{array}{c}2.396^{* * *} \\
(2.0)\end{array}$ & $\begin{array}{c}5.286 * * \\
(3.9)\end{array}$ \\
\hline log home GNP p.c. squared & $\begin{array}{c}-0.081 \\
(-1.1)\end{array}$ & $\begin{array}{c}-0.149 \\
(-0.8)\end{array}$ & $\begin{array}{c}0.087 \\
(0.8)\end{array}$ & $\begin{array}{c}-0.148^{* *} \\
(-3.2)\end{array}$ & $\begin{array}{c}-0.064 \\
(-0.7)\end{array}$ & $\begin{array}{c}-0.347 * * \\
(-4.5)\end{array}$ \\
\hline Political situation & & & & & & \\
\hline political rights, civil liberties & $\begin{array}{c}-0.002 \\
(-0.1)\end{array}$ & $\begin{array}{c}0.030 \\
(0.8)\end{array}$ & $\begin{array}{c}-0.090 * \\
(-1.8)\end{array}$ & $\begin{array}{c}-0.090 * * \\
(-4.5)\end{array}$ & $\begin{array}{c}-0.041 * \\
(-1.8)\end{array}$ & $\begin{array}{c}-0.182 * * \\
(-4.8)\end{array}$ \\
\hline political terror scale & $\begin{array}{c}0.239 * * \\
\quad(3.3)\end{array}$ & $\begin{array}{c}0.210^{* *} \\
\quad(2.3)\end{array}$ & $\begin{array}{c}0.381 * * \\
(3.1)\end{array}$ & $\begin{array}{c}0.026 \\
(0.5)\end{array}$ & $\begin{array}{c}-0.035 \\
(-0.6)\end{array}$ & $\begin{array}{c}0.052 \\
(0.6)\end{array}$ \\
\hline Links to Germany & & & & & & \\
\hline log migrant stock in Germany & $\begin{array}{c}1.319 * * \\
(11.0)\end{array}$ & $\begin{array}{c}1.520 * * \\
(8.9)\end{array}$ & $\begin{array}{c}1.010 * * \\
(5.8)\end{array}$ & $\begin{array}{c}0.743 * * \\
(9.5)\end{array}$ & $\begin{array}{c}0.878 * * \\
\quad(8.7)\end{array}$ & $\begin{array}{c}0.219 \\
(1.6)\end{array}$ \\
\hline log trade with Germany & $\begin{array}{c}-0.434 * * \\
(-3.8)\end{array}$ & $\begin{array}{c}-0.550 * * \\
(-3.3)\end{array}$ & $\begin{array}{l}0.227 \\
(0.9)\end{array}$ & $\begin{array}{c}0.174^{* *} * \\
(2.4)\end{array}$ & $\begin{array}{l}-0.085 \\
(-1.0)\end{array}$ & $\begin{array}{c}0.976^{* *} \\
(5.5)\end{array}$ \\
\hline Home country characteristics & & & & & & \\
\hline share of urban population & $\begin{array}{c}0.009 \\
(0.7)\end{array}$ & $\begin{array}{c}0.041 * \\
(1.7)\end{array}$ & $\begin{array}{c}-0.001 \\
(-0.1)\end{array}$ & $\begin{array}{c}-0.014 \\
(-1.6)\end{array}$ & $\begin{array}{c}0.010 \\
(0.7)\end{array}$ & $\begin{array}{c}-0.061 * * \\
(-4.0)\end{array}$ \\
\hline growth of labor force & $\begin{array}{c}9.010 \\
(0.7)\end{array}$ & $\begin{array}{c}46.235^{*} \\
(1.8)\end{array}$ & $\begin{array}{c}-11.817 \\
(-0.8)\end{array}$ & $\begin{array}{l}-4.646 \\
(-0.5)\end{array}$ & $\begin{array}{c}-70.967 * * \\
(-4.5)\end{array}$ & $\begin{array}{c}-3.758 \\
(-0.3)\end{array}$ \\
\hline log population & $\begin{array}{c}-0.054 \\
(-0.6)\end{array}$ & $\begin{array}{c}-0.059 \\
(-0.2)\end{array}$ & $\begin{array}{l}-0.151 \\
(-0.4)\end{array}$ & $\begin{array}{c}0.090^{*} \\
(1.7)\end{array}$ & $\begin{array}{c}0.739 * * \\
(3.5)\end{array}$ & $\begin{array}{l}-0.361 \\
(-1.4)\end{array}$ \\
\hline log distance to Germany & $\begin{array}{l}-0.700 \\
(-1.2)\end{array}$ & $\begin{array}{c}0.521 \\
(0.7)\end{array}$ & $\begin{array}{c}-2.080^{* *} \\
(-2.4)\end{array}$ & $\begin{array}{c}-1.215^{* *} \\
(-3.4)\end{array}$ & $\begin{array}{l}-0.478 \\
(-1.0)\end{array}$ & $\begin{array}{c}-2.111 * * \\
(-3.2)\end{array}$ \\
\hline Restrictions of German Law & & & & & & \\
\hline law 87 & $\begin{array}{l}-0.327 \\
(-1.4)\end{array}$ & $\begin{array}{c}-0.200 \\
(-0.7)\end{array}$ & $\begin{array}{c}-0.279 \\
(-0.8)\end{array}$ & $\begin{array}{c}-0.603^{* *} \\
(-3.6)\end{array}$ & $\begin{array}{c}-0.686^{* *} \\
(-3.6)\end{array}$ & $\begin{array}{c}-0.404 \\
(-1.4)\end{array}$ \\
\hline law 93 & $\begin{array}{c}-1.276 * * \\
(-6.4)\end{array}$ & $\begin{array}{c}-1.831 * * \\
(-6.5)\end{array}$ & $\begin{array}{c}-0.665^{* *} \\
(-2.5)\end{array}$ & $\begin{array}{c}-0.471 * * \\
(-3.6)\end{array}$ & $\begin{array}{c}-0.664 * * \\
(-4.3)\end{array}$ & $\begin{array}{c}-0.276 \\
(-1.4)\end{array}$ \\
\hline $\begin{array}{l}\text { Trend and constant } \\
\text { trend }\end{array}$ & $\begin{array}{c}0.050 \\
(0.9)\end{array}$ & $\begin{array}{c}0.068 \\
(0.8)\end{array}$ & $\begin{array}{c}0.053 \\
(0.8)\end{array}$ & $\begin{array}{c}0.070^{* * *} \\
(2.8)\end{array}$ & $\begin{array}{c}0.050 * \\
(1.7)\end{array}$ & $\begin{array}{c}0.069 * \\
(1.7)\end{array}$ \\
\hline constant & $\begin{array}{l}-120.3 \\
(-1.2)\end{array}$ & $\begin{array}{c}-170.8 \\
(-1.1)\end{array}$ & $\begin{array}{l}-89.2 \\
(-0.7) \\
\end{array}$ & $\begin{array}{c}-147.4 * * \\
(-3.0) \\
\end{array}$ & $\begin{array}{c}-117.8^{* *} \\
(-2.1)\end{array}$ & $\begin{array}{c}-131.4 * \\
(-1.7) \\
\end{array}$ \\
\hline Tests & & & & & & \\
\hline $\mathrm{R}^{2}$ & 0.49 & 0.59 & 0.30 & 0.39 & 0.55 & 0.35 \\
\hline Hausmann & 22.1 & 32.9 & 33.4 & 30.9 & 32.4 & 28.4 \\
\hline Breusch-Pagan & 1358.3 & 540.5 & 460.1 & 1719.4 & 795.0 & 556.2 \\
\hline
\end{tabular}

Note: $* *$ significant on the $5 \%$-level, * significant on the $10 \%$-level (two-side test) 
Figure 1: Inflows and asylum migration from developing countries
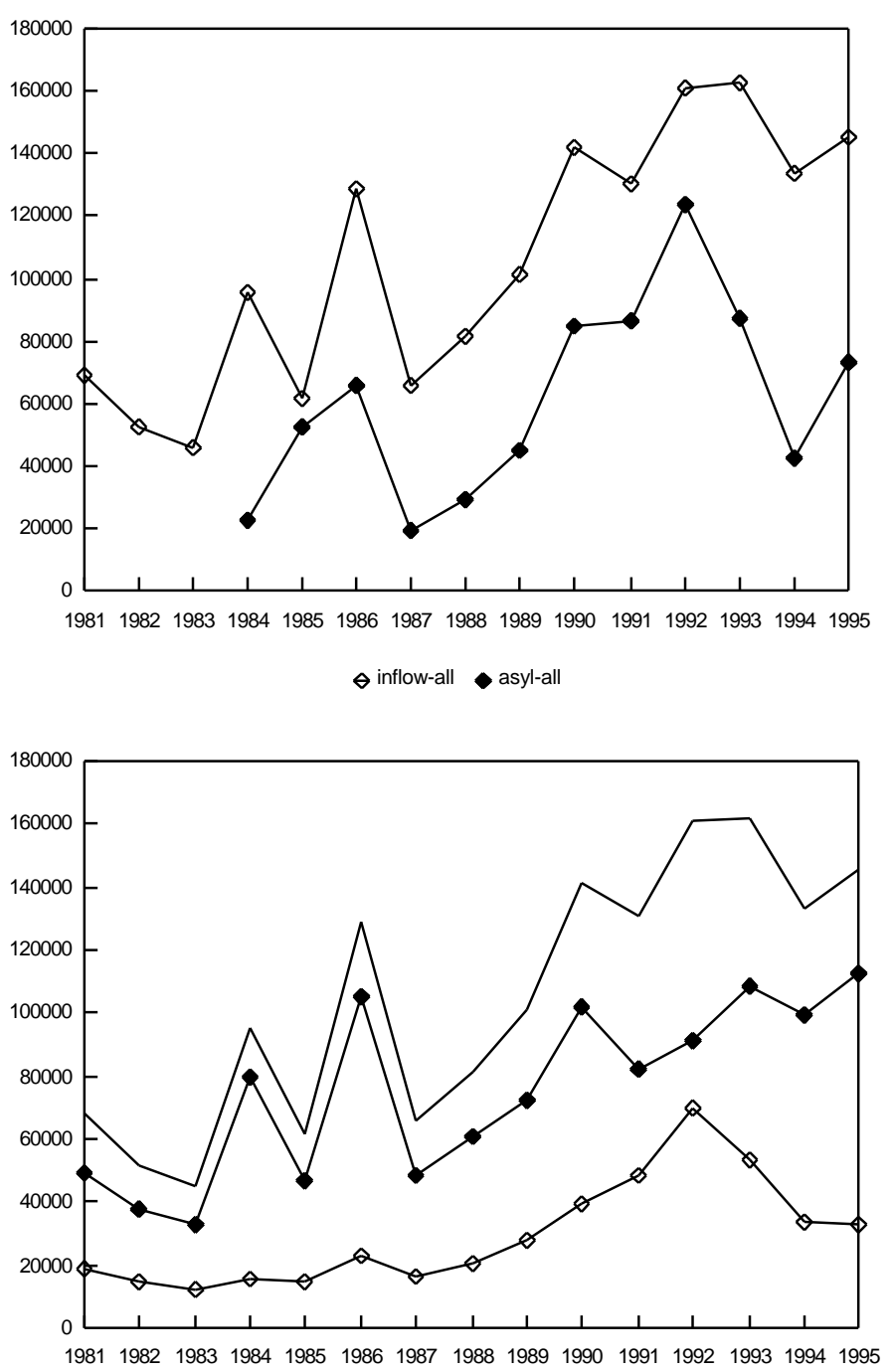

- inflow-all $\diamond$ inflow-africa $\diamond$ inflow-asia

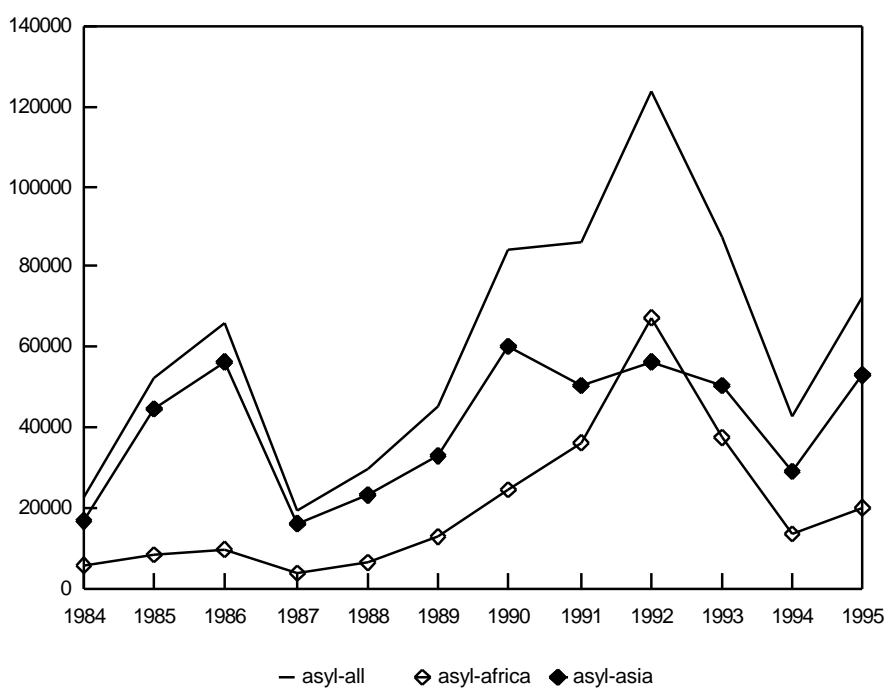

Note: Based on the 86 countries in the dataset 